\title{
EVALUASI PROGRAM PRAKTIK KERJA LAPANGAN INTEGRATIF FAKULTAS ILMU TARBIYAH DAN KEGURUAN UIN MALIKI MALANG
}

\author{
Nur Ali ${ }^{1}$
}

\begin{abstract}
Faculty of Tarbiyah and Teaching Training Maulana Malik Ibrahim State Islamic University Malang as Educational institute of teacher training has participatedin educating the students to be a professional teachers atelementary, junior and senior high schools. One of the way to realize it is through conducting teaching practicum in micro-teaching atcampus and integrated teaching practicum program at madrasah and schools.

This research isto know how was the guidance teachers and principals of madrasahs and schools towards the competences of students in conducting integrated teaching practicum program at madrasah and schools. It used survey design because it was influenced by the development of socials and eduational policy.

The results of this research showed that the evaluation of guidance teachers and principals of madrasahs and schoolstowards the competences of the students in conducting integrated teaching practicum program at madrasah and schools was good.
\end{abstract}

Keywords: profesional, personal, dan social competence.

\section{A. Pendahuluan}

Pendidikan nasional bertujuan untuk berkembangnya potensi peserta didik agar menjadi manusia yang beriman dan bertaqwa kepada Tuhan Yang Maha Esa, berakhlak mulia, sehat, berilmu, cakap, kreatif, mandiri, dan menjadi warga negara yang demokratis serta bertanggungjawab (UUSPN, No. 20/ 2003).Untuk mewujudkan hal tersebut, maka Tarbiyah (sekarang berubah menjadi Fakultas Ilmu Tarbiyah dan Keguruan) Universitas Islam Negeri (UIN) Maulana Malik Ibrahim Malang sebagai Lembaga pendidikan tenaga kependidikan (LPTK) turut berpartisipasi dengan jalan mencetak tenaga kependidikan atau guru kelas SD/MI-SLTP-SLTA/MTs-MA yang profesional. Cara yang ditempuh antara lain melalui melatih mahasiswa untuk menjadi

1 Dosen Fakultas Ilmu Tarbiyah dan Keguruan Universitas Islam Negeri Maulana Malik Ibrahim Malang Jl. Gajayana No.50 Malang 65144 
Nur Ali - Evaluasi Program Praktik Kerja Lapangan Integratif...

guru professional melalui dua tahap yaitu praktek mengajar di microteaching (PPL I) di kampus dan program kerja lapangan Integratif (PKLI) di madrasah dan sekolah yang dipilih menjadi lokasi PKLI.

PPL I merupakan kegiatan latihan mengajar terbimbing di hadapan para teman-temannya sesama mahasiswa di kelas kecil.Setiap mahasiswa diminta untuk menyusun suatu desain pembelajaran mata pelajaran tertentu dan kemudian mempraktikkan desain tersebut dengan menjadikan teman-temannya sebagai muridnya secara bergantian. Dalam mempraktikkan desain pembelajaran ini, setiap mahasiswa dituntut untuk mengimplementasikan berbagai teori-teori pendidikan dan belajar-mengajar serta beberapa strategi pembelajarannya.Setelah selesai mempraktikkan desainnya, dosen pembimbing dan temantemannya yang menjadi muridnya memberikan komentar-komentar, evaluasi dan refleksi terhadap hasil kegiatan praktiknya tersebut. Hasil dari refleksi tersebut menjadi masukan bagi setiap mahasiswa yang menjadi peserta PPL I untuk memperbaiki dan mengembangkannya serta menjadikannya sebagai bahan persiapan awal dalam mengikuti kegiatan PKLI. Sedangkan PKLI merupakan suatu kegiatan intra kurikuler yang berstatus sebagai mata kuliah yang wajib dikuti oleh semua mahasiswa calon guru pada Fakultas Tarbiyah UIN Maliki Malang. PKLI ini merupakan proses perpaduan berbagai komponen pengetahuan teoritis-praktis dengan praktik pengalaman di lapangan yang diwujudkan dalam bentuk tiga kegiatan yaitu; praktik mengajar di kelas pada lokasi sekolah-madrasah praktikan atau PPL II, Penelitian Tindakan kelas (PTK), dan pengabdian kepada masyarakat dengan sasaran masyarakat sekolah-madrasah(FITK UIN Maliki Malang, 2010, hal. 1) agar mereka memiliki pemahaman, pengalaman, dan wawasan tentang empat kompetensi yaitu; (1) kompetensi pedagogik, (2) kompetensi profesional, (3) kompetensi sosial, dn (4) kompetensi personal (PP. 19 tahun 2005) atau menurut Permenag 16 tahun 2010, ada lima kompetensi untuk Guru Pendidikan Agama Islam yaitu; (1) kompetensi pedagogik, (2) kompetensi profesional, (3) kompetensi sosial, (4) kompetensi personal dan (5)kompetensi kepemimpinan. Untuk mewujudkan itu, kegiatan PKLI mahasiswa Fakultas FITK dilaksanakan di sekolah-madrasah.

Praktik kerja lapangan kependidikan atau PPL merupakan muara dari seluruh program pendidikan di lembaga pendidikan guru, karena itu program tersebut dapat dianggap sebagai program 
yang mengintegrasikan segala kemampuan keguruan yang telah diperoleh selama mahasiswa belajar di Perguruan Tinggi. D.N. Medley (dalam Muhadjir, N. 1993, hal. 61-62)) melacak asumsi yang melandasi penyelenggaraan pendidikan guru lewat obyek-obyek penelitian yang dipilih oleh para ahli untuk menemukan keberhasilan guru dan pendidikan guru serta pengembangannya.Medley membagi asumsi yang melandasi keberhasilan guru dan pendidikan guru menjadi empat fase. Fase pertama (sekitar tahun 1930-an) penelitian terfolus pada sifat-sifat kepribadian guru. Fase kedua, penelitian terfokus pada eksperimentasi berbagai metode mengajar. Fase ketiga para ahli memusatkan penelitiannya pada iklim interaksi di dalam kelas. Dan Fase keempat memusatkan perhatian pada munculnya penampilan (performance) yang menggambarkan bahwa dia memiliki kemampuan (competency). Penampilan yang beragam karena konteks spesifik, tahu alasannya dan dapat mempertanggungjawabkan alternatif pilihannya itulah yang dituntutkan para ahli kelompok keempat. Calon guru dievaluasi kemampuan mengajarnya berdasarkan pada penampilannya. Yang termasuk di dalamnya adalah penguasaan materi, penguasaan alternatif strategi penyampaiannya, penguasaan alternatif media yang tepat, dan lain-nya).

Hasil penelitian Muhaimin, dkk. (2000) yang melacak tentang etos kerja guru pendidikan agama Islam dan upaya pengembangan profesinya melaporkan bahwa upaya pengembangan profesi guru yang dilakukan oleh lembaga pendidikan, Musawaroh Guru Mata Pelajaran (MGMP) dan dari Depag dan Diknas baik yang lewat kegiatan penataran, dilklat, maupun seminar lebih banyak berorientasi pada aspek profesional terutama yang berkaitan dengan penyusunan pelajaran dalam kegiatan belajar mengajar dan metodologi pembelajaran. Sedangkan untuk bidang penelitian kegiatan belajar mengajar, pengembangan aspek sosial dan personal kurang mendapatkan perhatian yang sungguh-sungguh. Akibat dari kurangnya perhatian terhadap pengembangan di bidang penelitian kegiatan belajar mengajar (classroom research) maka para guru kurang wawasan dalam inovasi pembelajaran.

Driyarkara (1980) juga melaporkan tentang pola pengembangan calon guru yang ada di negara-negera yang dianggap baik dalam bidang ini yang antara lain di Perancis, Inggris, Norwegia, Swedia, dan Denmark. Di Perancis, pendidikan guru diselenggarakan dengan kondisi-kondisi yang sangat berat. Mereka tidak cukup hanya dengan 
Nur Ali - Evaluasi Program Praktik Kerja Lapangan Integratif...

mempunyai ijazah atau diploma dari suatu fakultas keguruan tetapi masih harus ditambah dengan sertifikat kompetensi mengajar yang hal ini hanya dapat diperoleh sesudah praktik mengajar di lapangan selama dua tahun. Menurut Driyakarya, di Inggris, para calon guru yang sudah menamatkan pada universitas dan mengikuti kursus pedagogis dan mereka yang menamatkan perguruan tinggi pendidikan guru tidak dengan begitu saja dapat pangkat guru. Mereka masih harus mengalami masa percobaan selama satu tahun. Jika ternyata hasilnya tidak memuaskan, maka diploma keguruan yang sudah diperoleh itu dicabut kembali. Sedangkan di Norwegia, Swedia, dan Denmark pendidikan calon guru sekolah lanjutan memerlukan waktu 6 sampai 6,5 tahun. Bagi para lulusan pendidikan tinggi pada suatu jurusan ilmu tertentu dianggap belum lengkap untuk melak-sanakan tugas guru sebelum mereka harus mengikuti pelajaran keguruan lagi selama 1 tahun. Setelah itu, mereka baru boleh melaksanakan tugas guru dan dapat dijadikan sebagai guru tetap.

Hasil studi Negara-negara berkembang, guru memberikan sumbangan dalam prestasi belajar siswa (36\%), selanjutnya manajemen $(23 \%)$, waktu belajar siswa (22\%), dan sarana fisik (19\%).Aspek yang berkaitan dengan guru meliputi; mutu guru/citra dan kesejahteraan (Indra Djati S. 2000).

Tujuan penelitian ini adalah untuk mengetahui; (i) Penilaian para guru pamong di madrasah dan sekolah negeri terhadap kompetensi professional mahasiswa PKLI Fakultas Tarbiyah UIN Maliki Malang, (ii) Penilaian para kepala madrasah dan sekolah negeri terhadap kompetensi personal dan sosial mahasiswa PKLI Fakultas Tarbiyah UIN Maliki Malang. Dan (iii) Faktor apa saja yang menghambat pelaksanaan program PKLI mahasiswa Fakultas Tarbiyah UIN Maliki Malang di madrasah dan sekolah negeri.

\section{B. Kajian Pustaka}

1. Praktik Kerja Lapangan Integratif UIN Maliki Malang

Program Kerja Lapangan Integratif (PKLI) adalah suatu kegiatan intra kurikuler yang berstatus sebagai mata kuliah yang wajib dikuti oleh semua siswa calon pendidik/guru untuk memenuhi persyaratan profesinya (Prosedur mutu fakultas tarbiyah, 2009; FT. UIN Maliki 
Malang, 2010, hal. 1). PKLI ini merupakan proses perpaduan berbagai komponen pengetahuan teoritis-praktis dengan praktik pengalaman di lapangan yang diwujudkan dalam bentuk tiga kegiatan yaitu; praktik mengajar di kelas pada lokasi sekolah-madrasah praktikan atau PPL II, Penelitian Tindakan kelas (PTK), dan pengabdian kepada masyarakat dengan sasaran masyarakat sekolah-madrasah (FITK UIN Maliki Malang, 2010, hal. 1) agar mereka memiliki pemahaman, pengalaman, dan wawasan tentang empat kompetensi yaitu; (1) kompetensi pedagogik, (2) kompetensi profesional, (3) kompetensi sosial, dan (4) kompetensi personal (PP. 19 tahun 2005). Sedangkan untuk guru pendidikan agama islam (GPAI), menurut Permenag 16 tahun 2010 tentang pengelolaan pendidikan agama pada sekolah pada pasal 1 ayat (1) dinyatakan bahwa Guru Pendidikan Agama harus memiliki kompetensi pedagogik, kepribadian, sosial, profesional, dan kepemimpinan.

Kompetensi pedagogik GPAI meliputi: (i) pemahaman karakteristik peserta didik dari aspek fisik, moral, sosial, kultural, emosional, dan intelektual, (ii) penguasaan teori dan prinsip belajar pendidikan agama, (iii) pengembangan kurikulum pendidikan agama, (iv) penyelenggaraan kegiatan pengembangan pendidikan agama, (v) pemanfaatan teknologi informasi dan komunikasi untuk kepentingan penyelenggaraan dan pengembangan pendidikan agama, (vi) pengembangan potensi peserta didik untuk mengaktualisasikan berbagai potensi yang dimiliki dalam bidang pendidikan agama, (vii) komunikasi secara efektif, empatik, dan santun dengan peserta didik, (vii) penyelenggaraan penilaian dan evaluasi proses dan hasil belajar pendidikan agama, (viii) pemanfaatan hasil penilaian dan evaluasi untuk kepentingan pembelajaran pendidikan agama, dan (ix) tindakan reflektif untuk peningkatan kualitas pembelajaran pendidikan.

Kompetensi kepribadian GPAI meliputi; (i) tindakan yang sesuai dengan norma agama, hukum, sosial, dan kebudayaan nasional Indonesia, (ii) penampilan diri sebagai pribadi yang jujur, berakhlak mulia, dan teladan bagi peserta didik dan masyarakat, (iii) penampilan diri sebagai pribadi yang mantap, stabil, dewasa, arif, dan berwibawa, (iv) kepemilikan etos kerja, tanggung jawab yang tinggi, rasa bangga menjadi guru, dan rasa percaya diri, serta (vii) penghormatan terhadap kode etik profesi guru. Kompetensi Sosial GPAI meliputi, (i) sikap inklusif, bertindak objektif, serta tidak diskriminatif berdasarkan jenis kelamin, agama, ras, kondisi fisik, latar belakang keluarga, dan status 
Nur Ali - Evaluasi Program Praktik Kerja Lapangan Integratif...

sosial ekonomi, (ii) sikap adaptif dengan lingkungan sosial budaya tempat bertugas, dan (iii) sikap komunikatif dengan komunitas guru, warga sekolah dan warga masyarakat. Kompetensi Profesional GPAI meliputi; (i) penguasaan materi, struktur, konsep, dan pola pikir keilmuan yang mendukung mata pelajaran pendidikan agama, (ii) penguasaan standar kompetensi dan kompetensi dasar mata pelajaran pendidikan agama, (iii) pengembangan materi pembelajaran mata pelajaran pendidikan agama secara kreatif, (iv) pengembangan profesionalitas secara berkelanjutan dengan melakukan tindakan reflektif, dan (v) pemanfaatan teknologi informasi dan komunikasi untuk berkomunikasi dan mengembangkan diri.

Sedangkan Kompetensi kepemimpinan GPAI meliputi; (i) kemampuan membuat perencanaan pembudayaan pengamalan ajaran agama dan perilaku ak hlak mulia pada komunitas sekolah sebagai bagian dari proses pembelajaran agama, (ii) kemampuan mengorganisasikan potensi unsur sekolah secara sistematis untuk mendukung pembudayaan pengamalan ajaran agama pada komunitas sekolah, (iii) kemampuan menjadi inovator, motivator, fasilitator, pembimbing dan konselor dalam pembudayaan pengamalan ajaran agama padakomunitas sekolah, serta (iv) kemampuan menjaga, mengendalikan, dan mengarahkan pembudayaan pengamalan ajaran agama pada komunitas sekolah dan menjaga keharmonisan hubungan antar pemeluk agama dalam bingkai Negara Kesatuan Republik Indonesia.

Adapun tujuan PKLI FITK UIN Maliki Malang adalah agar siswa calon guru mendapatkan pengalaman kependidikan secara nyata di lapangan sebagai wahana terbentuknya tenaga kependidikan professional, yaitu tenaga kependidikan yang memiliki seperangkat pengetahuan, keterampilan, nilai, sikap dan prilaku yang diperlukan bagi profesinya serta mampu menerapkan dalam penyelenggaraan pendidikan dan pengajaran di sekolah-madrasah maupun di luar sekolah-madrasah.

Untuk mewujudkan itu, kegiatan PKLI siswa FITK biasanya dilaksanakan di sekolah-madrasah di wilayah Malang Raya baik yang berstatus negeri maupun swasta. Menurut buku Prosedur mutu fakultas tarbiyah tahun 2008/2009, sekolah-madrasah yang dijadikan tempat latihan calon guru professional dengan profil yaitu; (1) memiliki multi program (IPA, IPS, Bahasa dan Agama, (2) menerapkan school based management, (3) memiliki sarana dan prasarana yang 
lengkap, (4) memiliki kultur akademik yang kuat, (5) memiliki suasana religious sebagai wujud dari kedalaman spiritual, keagungan akhlak dan kematangan professional, dan (6) mempunyai visi dan misi yang sama untuk ikut aktif dalam pengembangan madrasah.

2. Kedudukan dan Peranan Guru dalam Kegiatan Proses Belajar Mengajar

Guru merupakan salah satu komponen manusiawi dalam kegiatan proses belajar mengajar yang ikut berperan dalam pembentukan sumber daya manusia yang potensial di bidang pembangunan. Dalam arti khusus dapat dikatakan bahwa pada setiap diri guru terletak tanggungjawab untuk membawa siswanya pada suatu kedewasaan atau tingkat kematangan (mastery) tertentu. Karena itu, dalam kegiatan proses belajar mengajar guru memiliki kedudukan sebagai berikut;

1. Guru sebagai pengajar yakni melaksanakan transfer of knowledge

2. Guru sebagai pembimbing yakni menuntun dan mengarahkan siswa dalam belajar

3. Guru sebagai pendidik yakni melaksanakan transformasi nilai (transfer of values) (Sardjito, 1990: 1)

Dalam proses belajar mengajar, guru juga mempunyai tugas untuk mendorong, membimbing, dan memberi fasilitas belajar bagi murid murid untuk mencapai tujuan, Guru mempunyai tanggungjawab untuk melihat segala sesuatu yang terjadi dalam kelas untuk membantu proses perkembangan anak. Penyampaian materi pelajaran hanyalah merupakan salah satu dari bebagai kegitan dalam proses belajar mengajar.

Dengan demikian dapat dikatakan bahwa peranan guru dalam proses belajar mengajar sangat penting, Disamping itu peranan guru dalam menciptakan interaksi dengan siswa adalah sangat strategis, karena keterlibatan aktif seorang guru dalam suatu proses kerja pada proses penampilannya itu, ia tampil sebagai sesuatu yang dimainkan (Piet A. dan Ida A. Sahertian, 1990:34).

Berkenaan dengan peranan guru tersebut diatas , maka secara lebih terinci tugas guru dapat berpusat pada; (i) Mendidik anak dengan titik berat memberikan arah dan motivasi pencapaian tujuan baik jangka pendek maupun jangka panjang,: (ii) Memberi fasilitas pencapaian tujuan melalui pengalaman belajar yang memadai, dan (iii) Membantu 
Nur Ali - Evaluasi Program Praktik Kerja Lapangan Integratif...

perkembangan aspek-aspek pribadi seperti sikap,nilai-nilai, dan penyesuaian diri (Slameto, 1991:99).

Dengan demikian, dalam proses belejar mengajar guru tidak terbatas sebagai penyampai ilmu pengetahuan, akan tetapi lebih dari itu ia bertanggung jawab akan kesuluruhan perkembangan kepribadian siswa. Ia harus mampu menciptakan proses belajar yang sedemikian rupa sehingga dapat merangsang siswa untuk belajar secara aktif dan dinamis dalam memenuhi kebutuhan dan menciptaka tujuan.

Di samping itu, perkembangan ilmu dan teknologi serta perkembangan sosial budaya yang berlangsung dengan cepat telah memberikan tantangan kepada setiap individu. Setiap individu senantiasa ditantang untuk terus selalu belajar untuk dapat menyesuaikan diri sebaik-baiknya. Kesempatan belajar makin terbuka melalui berbagai sumber dan media. Anak-anak masa kini dapat belajar dari berbagai sumber dan media seperi surat kabar, radio, televisi, film, dan sebagainya. Ia dapat belajar dalam berbagai kesempatan dan kegiatan diluar sekolah. Guru hanya merupakan salah satu diantara berbagai sumber dan media belajar. Maka dengan demikian peranan guru dalam belajar inimenjadi lebih luas dan lebih mengarah kepada peningkatan motivasi belajar anakanak.Melalui peranannya sebagai pengajar, guru diharapkan mampu mendorong anak untuk senantiasa belajar dalam berbagai kesempatan melalui berbagai sumber dan media. Guru hendaknya mampu membantu setiap anak untuk secara efektif dapat mempergunakan berbagai kesempatan belajar dan berbagai sumber serta media belajar. Hal ini berarti bahwa guru hendaknya dapat mengembangkan cara dan kebiasaan belajar yang sebaik-baiknya serta memberikan fasilitas yang memadai sehingga siswa dapat belajar secara efektif.

Dari uraian di atas, dapat dikatakan bahwa peranan guru telah meningkat dari sebagai pengajar menjadi direktur pengarah belajar (director of learning).Sebagai derektur belajar, tugas dan tanggung jawab guru menjadi lebih meningkat yang didalamnya termasuk fungsi-fungsi guru sebagai perencana pengajaran, pengelola pengajaran, penilai hasil belajar, sebagai motivator belajar, dan sebagai pembimbing.(Dick W. dan Carey L., 1985:5-7). 
Dengan demikian proses belajar mengajar akan senantiasa ditingkatkan terus menerus dalam mencapai hasil belajar yang optimal. Sejalan dengan itu, Degeng dan Yusuf Hadimiarso (1990:229) mengajukan 4 hal yang harus dipenuhi oleh seorang pengelola pengajaran, yaitu:

1. Penjadwalan penggunaan strategi pengajaran.

2. Pembuatan catatan kemajuan belajar siswa .

3. Pengelolaan motivasional dan

4. Kontrol belajar.

Diantara keempat hal tersebut diatas, kontrol belajar memerlukan perhatian lebih serius dalam upaya memperskripkan strategi pengelolaan pengajaran, karena ia secara langsung dapat memberi petunjuk bagaimana sebaiknya menata hubungan antara setiap siswa dengan pengajaran.

Dalam hubungan ini guru mempunyai fungsi sebagai motivator dalam keseluruhan kegiatan belajar mengajar. Dalam kaitanya dengan motivasi pada proses belajar mengajar. Slameto (1991:101-102) mengemukakan 4 hal yang dapat dikerjakan guru dalam memberikan motivasi ini yaitu:

1. Membangkitkan dorongan kepada siswa untuk belajar.

2. Menjelaskan secara kongkrit kepada siswa apa yang dapat dilakuakan pada akhir pengajaran.

3. Memberikan ganjaran terhadap prestasi yang dicapai sehingga dapat merangsang untuk mencapai prestasi yang lebih baik di kemudian hari, dan

4. Membentuk kebiasaan belajar yang baik.

Sebagai direktur belajar, pendekatan yang diperlukan dalam proses belajar mengajar tidak hanya melalui pendekatan instruksional, akan tetapi disertai dengan pendekatan pribadi. Melalui pendekatan pribadi ini diharapkan guru dapat mengenal dan memahamai siswa secara lebih mendalam sehinggga dapat membantui dalam keseluruhan proses belajarnya. Dengan perkataan lain, sebagai direktur belajar, guru sekaligus berperanan sebagi pembimbing dalam proses belajar mengajar. 
Nur Ali - Evaluasi Program Praktik Keria Lapangan Integratif...

\section{Mutu Pendidikan dan Profil Guru Profesional}

Mutu pendidikan berkaitan dengan komponen seperti input, proses, output, sarana dan prasarana serta biaya yang tersedia. Namun yang memiliki peran yang sangat penting adalah pendidik yang berkualitas. Undang-undang nomor 14 tahun 2005 tentang guru dan guru pada pasal 4 menyatakan bahwa guru sebagai agen pembelajaran berfungsi untuk meningkatkan mutu pendidikan nasional. Untuk mendukung harapan ini, pemerintah Indonesia melalui kemendiknas telah mengeluarkan Permendiknas no 16 tahun 2007 tentang standar kualifikasi dan kompetensi guru. Kompetensi yang dimaksud dalam permendiknas tersebut yaitu kompetensi pedagogik, professional, sosial dan personal. Sedangkan menurut Permenag nomor 16 tahun 2010 tentang pengelolaan pendidikan agama pada sekolah menyebutkan bahwa GPAI harus memiliki lima kompetensi yaitu; kompetensi pedagogik, kompetensi kepribadian, kompetensi sosial, kompetensi professional, dan kompetensi kepemimpinan (Permenag 16/2010, pasal 16.

Berkaitan dengan mutu pendidikan dan profil guru professional, H.A.R Tilar $(1999 ; 23)$ menyatakan bahwa pendidik atau guru abad 21 harus memenuhi 4 kriteria yaitu (1) mempunyau kepribadian yang matang (mature and developing personality) (2) menguasai ilmu pengetahuan dan teknologi, (3) mempunyai keterampilan untuk membangkitkan minat peserta didik, dan (4) mengembangkan profesinya secara kesinambungan. (H.A.R Tilaar, Beberapa Agenda Reformasi Pendidikan Nasional dalam Perspektif Abad 21; Magelang: Indonesia Tera, 1999, hal. 23) . Sedangkan Menurut Muhaimin $(2003 ; 217)$ guru professional harus mempunyai karakteristik yaitu (1) komitmen terhadap profesionalitas yang melekat pada dirinya sikap dedikatif, komitmen terhadap mutu proses dan hasil kerja serta sikap continous improvement, (2) menguasai ilmu dan mampu mengembangkan serta menjelaskan fungsinya dalam kehidupan, menjelaskan dimensi teoritis dan praktisnya atau sekaligus melakukan "transfer" ilmu/pengetahuan, internalisasi serta amaliyah, (3) memiliki kepekaan intelektual dan informasi serta memperbaharui pengetahuan dan keahliannya secara berkelanjutan dan berusaha mencerdaskan peserta didiknya, memberantas kebodohan mereka serta melatih keterampilan sesuai dengan bakat, minat dan kemampuannya. (muhaimin. Wacana Pengembangan Pendidikan Islam. Yogjakarta: Pustaka Pelajar, 2003, hal. 217). Adapun pendapat Asian Institut for Teacher Education sebagaimana yang dirujuk oleh Gumelar dan Dahyat, 
2002) mengemukan bahwa kompetensi professional guru mencakup kemampuan dalam (1) mengerti dan menerapkan landasan pendidikan baik filosofis, psikologis, dan sebagainya, (2) mengerti dan menerapkan teori belajar sesuai dengan tingkat perkembangan perilaku peserta didik, (3) mampu menangani mata pelajaran atau bidang studi yang ditugaskan kepadanya, (4) mengerti dan dapat menerapkan metode mengajar yang sesuai, (5) mampu menggunakan berbagai alat pelajaran dan media serta fasilitas belajar lain, (6) mampu mengorganisasikan dn melaksanakan program pengajaran, (7) mampu melaksanakan evaluasi belajar, dan (8) mampu menumbuhkan motivasi peserta didik. (Gumelar dan Dahyat, Jakarta: gramedia, 2002).

Dengan demikian, secara umum profesi dimaknai sebagai suatu pekerjaan yang memerlukan pendidikan lanjut di dalam science dan teknologi yang digunakan sebagai perangkat dasar untuk diimplementasikan dalam berbagai kegiatan yang bermanfaat. Sedangkan guru sebagai salah satu komponen manusiawi dalam kegiatan proses belajar mengajar berperan dalam pembentukan sumber daya manusia yang potensial di bidang pembangunan. Oleh sebab itu, profesi guru merupakan suatu jabatan yang mempunyai kekhususan dan memerlukan kelengkapan keterampilan tertentu, karena pada setiap guru terletak tanggung jawab untuk membawa siswanya pada suatu kedewasaan atau tingkat kematangan.

Permendiknas nomor 16 tahun 2007 tentang kualifikasi akademik dan kompetensi guru mengklasifikasikan kompetensi yang harus dimiliki seseorang untuk menjadi guru professional yaitu; (i) Menguasai materi, struktur, konsep, dan pola pikir keilmuan yang mendukung mata pelajaran yang diampu, (ii) Menguasai standar kompetensi dan kompetensi dasar mata pelajaran/bidang pengembangan yang diampu, (iii) Mengembangkan materi pembelajaran yang diampu secara kreatif, (iv) Mengembangkan keprofesionalan secara berkelanjutan dengan melakukan tindakan reflektif, dan (v) Memanfaatkan teknologi informasi dan komunikasi untuk berkomunikasi dan mengembangkan diri.

Untuk menjadi guru yang berkompeten, calon guru perlu belajar dan berlatih secara sungguh-sungguh selama kurun waktu tertentu dalam menerapkan berbagai keterampilan mengajar dan model-model mengajar. Beberapa model mengajar yang dianggap komprehensif adalah model set yang dikembangkan oleh Bruce Joye dan Marsha Weil (1989) 
Nur Ali - Evaluasi Program Praktik Keria Lapangan Integratif...

dengan kategori sebagai berikut yaitu; (1) model information processing, model ini perlu dipelajari dan diterapkan dalam proses belajar mengajar agar ranah cipta siswa dapat berkembang dan berfungsi seoptimal mungkin, (2) model personal yang berorientasi pada pengembangan pribadi siswa dengan memperhatikan ranah rasa, terutama fungsi emosionalnya, (3) model social yang menitikberatkan pada proses interaksi antar individu yang terjadi dalam kelompok individu. (4) model behavioral dimana aktivitas mengajar menurut teori ini harus ditujukan pada timbulnya perilaku baru atau berubahnya perilaku siswa kea rah yang se jalan dengan harapan.

Menurut Crow and Alice Crow (1985) kompetensi guru meliputi (1) penguasaan subjek mater yang akan diajarkan, (2) keadaan fisik dan kesehatan, (3) sifat[-sifat pribadi dan control emosi, (4) memahami sifat hakikat dan perkembangan manusia, (5) mengetahui dan mampu menetapkan prinsip-prinsip belajar, (6) peka dan aspiratif terhadap perbedaan kebudayaan, agama, etnis, dll. Dan (7) berminat terhadap perbaikan profesionalisme dan pengayaan kultur yang secara terus menerus dilakukan. Sedangkan menurut Uzer Usman (2001) tugas guru professional meliputi mendidik, mengajar, dan berlatih.Mendidik berarti meneruskan dan mengembangkan nilai-nilai hidup, Mengajar berarti meneruskan dan mengembangkan ilmu pengetahuan dan teknologi, dan melatih berarti mengembangkan keterampilan-keterampilan pada siswa. Guru yang professional sebaiknya memiliki 4 kompetensi yaitu; (1) menguasai bidang studi dan materi yang akan diajarkan, (2) memiliki system penyampaian pengetahuan yang meliputi prinsip, metode, pengenalan siswa, penilaian dan bimbingan belajar, (3) memiliki kepribadian yang berwibawa.

Atas dasar itu, maka PKLI merupakan salah satu komponen kegiatan kurikuler yang memerlukan keterpaduan antara penguasaan materi dan teori dengan praktik di lapangan.

\section{Metode Penelitian}

1. Rancangan Penelitian

Penelitian ini dirancang dalam bentuk penelitian survei, karena penelitian survei merupakan salah satu jenis penelitian yang banyak dipengaruhi oleh perkembangan sosiologis dan dilaksanakan untuk bermacam-macam maksud, termasuk di dalamnya bidang pendidikan. 
Jenis penelitian ini juga sering digunakan untuk mengumpulkan informasi yang berhubungan dengan minat dan persoalan-persoalan di bidang-bidang tertentu (Wayan Ardhana, 1987; 97)

\section{Lokasi Penelitian}

Berdasarkan pada data penempatan mahasiswa PKLI mulai tahun 2010 ditemukan sekolah dan madrasah yang selama ini ditempati PKLI FITK UIN Maliki Malang yang tersebar di wilayah Malang Raya, yang antara lain berada di wilayah Singosari, Batu, Klojen dan Lowokwaru. Sedangkan personel yang terlibat langsung dalam penilaian kompetensi mahasiswa PKLI di lapangan adalah kepala sekolah- madrasah, dan para guru pamong.Dengan demikian, populasi penelitian ini adalah mereka yang disebutkan di atas. Mengingat objek penelitian ini adalah PKLI Fakultas Tarbiyah di sekolah-madrasah, Maka dalam menentukan sampel digunakan teknik "purposive sampling" .

Adapun sampel penelitian ini meliputi; Kepala MIN, Kepala SMPN-SMAN, Kepala MTsN-MAN, dan guru pamong SMPN-SMAN, MIN, MTsN-MAN. Hal ini dasarkan pada pemikiran bahwa ketiga pihak tersebut dapat memantau perkembangan kompetensi mahasiswa setiap hari di sekolah dan masyarakat serta memiliki tugas dalam pembimbingan dan penilaian kompetensi mahasiswa PKLI Fakultas Tarbiyah di sekolah-madrasah.

\section{Analisis Data}

Dalam menjawab permasalahan penelitian ini, angket yang telah terkumpul diklasifikasikan dalam golongan kuesener untuk DPL, untuk guru pamong dan untuk kepala sekolah pada masing-masing sekolahmadrasah, yang kemudian dianalisis dengan statistik deskriptif.

Bagian pertama dari kuesener yaitu terdiri atas komponen-komponen kompetensi yang harus dinilai oleh DPL, kepala sekolah atau guru pamong masing-masing dijumlahkan skornya, lalu kemudian ditetapkan nilainya dengan rumus Z-skor. Untuk memperoleh kesimpulan tentang penilaian guru pamong untuk masing-masing sekolah-madrasah terhadap kompetensi mahasiswa PKLI Fakultas Tarbiyah UIN Maliki Malang, maka nilai yang diberikan oleh para guru pamong dari tiaptiap sekolah-madrasah diambil rata-ratanya. 
Nur Ali - Evaluasi Program Praktik Kerja Lapangan Integratif...

Dalam menentukan penilaian guru pamong, kepala sekolahmadrasah maupun DPL yang menjadi sampel penelitian terhadap kompetensi mahasiswa PKLI Fakultas Tarbiyah UIN Maliki Malang, digunakan kriteria yaitu; Nilai $85-100=$ Prestasi sangat baik, Nilai 70 - $84=$ Prestasi baik, Nilai $60-69=$ Prestasi cukup, Nilai $50-59=$ Prestasi kurang, dan Nilai 0 - 49 = Prestasi sangat kurang.

Sedangkan untuk menghilangkan faktor subjektifitas dari responden, peneliti menggunakan uji nilai standar atau disebut Z-skor dengan rumus

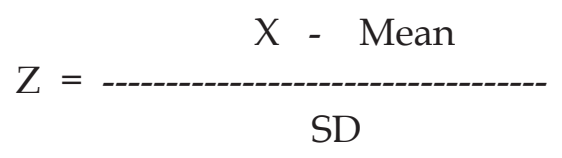

Data yang dikumpulkan melalui wawancara dan dokumentasi dianalisis yang dimulai dengan mengumpulkan data lapangan, mereduksi data, menyajikan data, dan akhirnya menarik kesimpulan/ verifikasi. Proses analisis data dimaksudkan sebagai suatu siklus interaktif. Sedangkan untuk menjaga kredebilitas (validitas) data, peneliti menggunakan teknik triangulasi, member check dan peer debriefing (Patton, 1980: 331, Lincoln dan Guba, 1985: 305)

\section{Hasil Penelitian dan Pembahasan}

Hasil penilaian guru pamong madrasah dan sekolah negeri terhadap kompetensi mahasiswa yang melaksanakan PKLI yaitu; (1) kompetensi professional yang terdiri atas (i) kompetensi menyusun persiapan tertulis meliputi; perumusan kompetensi dasar dan indikator, pengorganisasian isi bahan pembelajaran, kesesuaian pemilihan strategi pembelajaran,kemampuan menentukan langkah-langkah pembelajaran, ketepatan mendapatkan alokasi waktu dalam proses belajar mengajar, ketepatan menentukan alat, media, dan sumber belajar, ketepatan menentukan prosedur, jenis, dan alat penilaian, dan (ii) kompetensi mengajar di kelas meliputi; kemampuan membuka pelajaran, kemapuan menjelaskan, kemampuan menggunakan strategi pembelajaran, kemampuan menggunakan alat, media dan sumber belajar, kemampuan menanggapi dan merespon pertanyaan siswa, kemampuan menguasai 
isi bahan pelajaran, kemampuan menggunakan waktu secara tepat, kemampuan menutup pelajaran, kemampuan menilai pencapaian hasil pembelajaran. (2) kompetensi personal yang terdiri atas; Tanggung jawab, Kejujuran, Kedisiplinan, Kepemimpinan, Penyelesaian tugas, Kemampuan mengatasi masalah, Kerapian busana dan performance professional sebagai guru. Dan (3) kompetensi social mahasiswa PKLI Fakultas Tarbiyah UIN yang terdiri atas; Bekerjasama dengan Kepala Sekolah, Bekerjasama dengan Guru Pamong, Bekerjasama dengan Guru lain, Bekerjasama dengan karyawan sekolah, Bekerjasama dengan sesama teman praktikan, Hubungan dengan siswa, Kepahaman terhadap lingkungan sekolah, Kepahaman terhadap tugas dan lingkungan kerja di sekolah, Kepahaman terhadap tata cara pergaulan di lingkungan sekolah.

Berdasarkan data yang terkumpul terkait dengan kompetensi professional dari mahasiswa PKLI secara umum menunjukkan bahwa sebanyak 14 guru pamong (100\%) dari 14 Orang guru pamong yang dijadikan responden memberikan penilaian "baik" terhadap prestasi mahasiswa dalam melaksanakan kegiatan PPL II pada PKLI Fakultas Tarbiyah UIN Maliki Malang di madrasah dan sekolah negeri. Sedangkan beberapa aspek dari penilaian guru pamongmadrasah dan sekolah negeri terhadap kompetensi profesional mahasiswa PKLI Fakultas Tarbiyah UIN Maliki Malang yang mendapat penilaian rendah dan cukup adalah (i) Kompenen-komponen kompetensi professional yang mendapatkan penilaian "rendah" yaitu kemampuan menilai pencapaian hasil pembelajaran dan (ii) Kompenen-komponen kompetensi professional yang mendapatkan penilaian "cukup" meliputi; (i) ketepatan menentukan alat, media, dan sumber belajar, (ii) kemampuan menggunakan strategi pembelajaran, (iii) kemampuan menggunakan alat, media dan sumber belajar, (iv) kemampuan menggunakan waktu secara tepat.

Adapun penilaian kepala madrasah dan sekolah negeri terhadap kompetensi personal dan sosial mahasiswa PKLI Fakultas Tarbiyah UIN Maliki Malang berdasarkan data yang terkumpul menunjukkan bahwa sebanyak 14 orang (100\%) dari 14 kepala sekolah dan guru pamong negeri memberikan penilaian "baik" terhadap pelaksanaan kegiatan PPL II pada PKLI Fakultas Tarbiyah UIN Maliki Malang di madrasah dan sekolah negeri. Sedangkan beberapa aspek dari penilaian kepala madrasah dan sekolah negeri terhadap kompetensi personal dan 
Nur Ali - Evaluasi Program Praktik Kerja Lapangan Integratif...

social mahasiswa PKLI Fakultas Tarbiyah UIN Maliki Malang yang mendapat penilaian rendah dan cukup adalah (i) Kompenen kompetensi personal yang mendapatkan penilaian " rendah" yaitu kemampuan mengatasi masalah, sedangkan yang mendapatkan penilaian "cukup" adalah komponen tanggung jawab dan (ii)Kompenen kompetensi sosial yang mendapatkan penilaian "rendah" yaitu kemampuan bekerjasama dengan Kepala Sekolah.

Secara keseluruhan penilaian kepala sekolah dan guru pamong negeri terhadap kompetensi profesional, personal dan sosial mahasiswa PKLI Fakultas Tarbiyah UIN Maliki Malang pada madrasah dan sekolah yang menjadi lokasi penelitian memberikan penilaian dengan prestasi "baik" $100 \%$, dengan nilai yang terrendah yaitu MAN 2 Batu dengan nilai 76,69. MAN 2 Batu adalah madrasah berasrama "ma'had bilingual".

Permasalahan yang ketiga dari penelitian ini adalah faktor apa saja yang menghambat pelaksanaan PKLI mahasiswa Fakultas Tarbiyah UIN Maliki Malang selama melaksanakan kegiatan PPL II pada madrasah dan sekolah negeri yang menjadi lokasi penelitian. Untuk menjawab permasalahan ini sumber data yang digunakan adalah daftar isian subjektif yang terdapat dalam kuesener bagian kedua baik isian untuk guru pamong maupun kepala madrasah dan sekolah negeri yang berkaitan dengan hambatan yang ada dalam pelaksanaan kegiatan PPL II dan saran-saran untuk perbaikannya. Di samping itu, peneliti juga mengadakan wawancara dengan para guru pamong dan kepala madrasah dan sekolah negeri sehubungan dengan pelaksanaan kegiatan PPL II Mahasiswa fakultas Tarbiyah UIN Maliki Malang selama ini.

Mengingat komponen yang dinilai oleh masing-masing guru pamong dan kepala madrasah dan sekolah dibatasi, maka hambatan/ saran yang tidak berhubungan dengan komponen yang berhak dinilai, diabaikan/ ditolak. Komponen yang dinilai guru pamong terhadap kompetensi mahasiswa Fakultas Tarbiyah UIN Maliki Malang yang dibinanya adalah komponen profesional yang meliputi kegiatan penyusunan persiapan mengajar tertulis dan kemampuan mengajar di kelas. Sedangkan komponen yang dinilai kepala madrasah dan sekolah terhadap kompetensi mahasiswa Fakultas Tarbiyah UIN Maliki Malang adalah kompetensi personel dan Kompetensi Sosial. 
Berdasarkan data yang terkumpul, secara umum pelaksanaan kegiatan PKLI mahasiswa Fakultas Tarbiyah UIN Maliki Malang yang dijadikan sampel lokasi penelitian adalah rata-rata baik.

Adapun hambatan dan saran dari 14 guru pamong dan 7 kepala madrasah dan sekolah negeri pada 7 madrasah dan sekolah negeri yang menjadi lokasi penelitian menunjukkan bahwa hambatan-hambatan yang ada dalam pelaksanaans PKLI di antaranya yaitu: (i) ada $28,57 \%$ Guru pamong mengulang kembali materi yang telah diberikan oleh mahasiswa PKLI karena kurangnya penguasaan, (ii) ada $42,85 \%$ mahasiswa PKLI yang dalam melakukan strategi mengajarnya kurang menekankan partisipasi siswa, (iii) ada 35,71\% dari guru pamong yang mengeluhkan bahwa jadual pelaksanaan PKLI mengganggu disain pembelajaran bidang studi karena adanya pemenggalan waktu di saat kehadiran mahasiswa PKLI, (iv) ada $64,28 \%$ mahasiswa PKLI sering minta izin ke kampus untuk kepentingan perkuliahan pada saat bertugas, (v) ada 28,57 mahasiswa PKLI yang kurang cepat dalam mengatasi/menyelesaikan permasalahan pembelajaran di kelas, dan (vi) 57,14 mahasiswa PKLI yang kurang kreatif dan variatif dalam menggunakan dan memanfaatkan media pembelajaran.

Sedangkan Saran-saran Perbaikan dalam Pelaksanaan PKLI meliputi; (i) Dalam kegiatan pembekalan dan Micro Teaching khususnya pembuatan perangkat pembelajaran, pengembangan materi, jenis-jenis evaluasi dan implementasi strategi dalam PBM, mohon frekwensi praktiknya di tambah agar mahasiswa PKLI ketika dilapangan tidak banyak mengalami kesulitan pada hal-hal yang bersifak teknis, (ii) Mohon diadakan aturan yang jelas bagi mahasiswa PKLI yang sering minta izin di saat bertugas dengan alasan ada kepentingan perkuliahan, (iii) Materi pelajaran yang diajarkan di Madrasah dan Sekolah sebaiknya dikampus dipelajari terlebih dahulu oleh mahasiswa PKLI sehingga ada kesiapan yang memadai dalam mengajar. Dan (iii) Seyogjanya ada komunikasi antara mahasiswa PKLI dengan guru pamong sebelum terjun ke kelas.

\section{Kesimpulan dan Saran}

Kesimpulan yang dapat dikemukakan dalam penelitian ini meliputi; (i) Penilaian para guru pamong di madrasah dan sekolah negeri terhadap kompetensi professional mahasiswa PKLI Fakultas Tarbiyah UIN Maliki 
Nur Ali - Evaluasi Program Praktik Kerja Lapangan Integratif...

Malang yaitu bahwa sebanyak 14 guru pamong (100 \%) dari 14 Orang guru pamong yang dijadikan responden memberikan penilaian "baik" terhadap prestasi mahasiswa dalam melaksanakan kegiatan PKLI Fakultas Tarbiyah UIN Maliki Malang di madrasah dan sekolah negeri. Aspek dari kompetensi professional yang mendapatkan penilaian " rendah" yaitu kemampuan menilai pencapaian hasil pembelajaran, (ii) Kompenen-komponen kompetensi professional yang mendapatkan penilaian "cukup" meliputi; (a) ketepatan menentukan alat, media, dan sumber belajar, (b) kemampuan menggunakan strategi pembelajaran (c) kemampuan=menggunakan alat, media dan sumber belajar, (d) kemampuan menggunakan waktu secara tepat, (ii) Penilaian para kepala madrasah dan sekolah negeri terhadap kompetensi personal dan sosial mahasiswa PKLI Fakultas Tarbiyah UIN Maliki Malang yaitu bahwa secara umum guru pamong dan kepala sekolah pendidikan dasar dan menengah yang menjadi sampel penelitian memberikan penilaian dengan prestasi "baik" $100 \%$, dengan nilai yang terrendah yaitu penilaian di lokasi MAN 2 Batu dengan nilai 76,69. MAN 2 Batu adalah madrasah berasrama "ma'had bilingual" dan (iii) Beberapa faktor yang menghambat pelaksanaan program PKLI mahasiswa Fakultas Tarbiyah UIN Maliki Malang di madrasah dan sekolah negeri yaitu (i) ada 28,57\% Guru pamong mengulang kembali materi yang telah diberikan oleh mahasiswa PKLI karena kurangnya penguasaan, (ii) ada $42,85 \%$ mahasiswa PKLI yang dalam melakukan strategi mengajarnya kurang menekankan partisipasi siswa, (iii) ada 35,71\% dari guru pamong yang mengeluhkan bahwa jadual pelaksanaan PKLI mengganggu disain pembelajaran bidang studi karena adanya pemenggalan waktu di saat kehadiran mahasiswa PKLI, (iv) ada $64,28 \%$ mahasiswa PKLI sering minta izin ke kampus untuk kepentingan perkuliahan pada saat bertugas, (v) ada 28,57 mahasiswa PKLI yang kurang cepat dalam mengatasi/menyelesaikan permasalahan pembelajaran di kelas, dan (vi) 57,14 mahasiswa PKLI yang kurang kreatif dan variatif dalam menggunakan dan memanfaatkan media pembelajaran.

Adapun saran dari penelitian ini yaitu: (i) Penelitian ini hanya dirancang untuk meneliti kompetensi professional, personal dan sosial mahasiswa PKLI Fakultas Tarbiyah UIN Maliki Malang, (ii) Untuk meningkatkan kualitas kompetensi di bidang profesionalisme maka kegiatan pembekalan dan Micro Teaching (PPL II) khususnya (i) pembuatan perangkat pembelajaran, pengembangan materi, jenis- 
jenis evaluasi dan implementasi strategi dalam PBM, mohon frekwensi praktiknya di tambah agar mahasiswa PKLI ketika dilapangan tidak banyak mengalami kesulitan pada hal-hal yang bersifak teknis, dan (ii) materi pelajaran yang diajarkan di Madrasah dan Sekolah sebaiknya dikampus dipelajari terlebih dahulu oleh mahasiswa PKLI sehingga ada kesiapan yang memadai dalam mengajar.

\section{Daftar Pustaka}

Ardhana, Wayan.1987. Bacaan Pilihan dalamMetodePenelitian Pendidikan. Jakarta: Dirjen Dikti. Depdikbud. Proyek Pengembangan LPTK.

Bruce Joye dan Marsha Weil, 1989.Models of Teaching, New Jersey: Prentice Hall, Inc.

Buku Prosedur Mutu Fakultas Tarbiyah UIN Malang, 2009, Fak. Tarbiyah UIN Malang.

Crow and Alice Crow.1985, Educational Psykology. San Fransisco: American Book Company.

Degeng, I. Nyoman S \& Miarso, Y. Hadi, 1990.Buku Pegangan Teknologi Pendidikan: Terapan Teori Kognitif dalam Desain Pembelajaran. Jakarta: UT.

Dick, W. \& Carrey, L. 1985.The Systematic Design of Instruction. Glenview, Illinois: Scott, Foresman dan Company.

Driyarkara, 1980.Kumpulan Karangan Driyarkara tentang Pendidikan. Yogjakarta: Penerbit Yayasan Kanisius.

Fak.Tar. UIN Malang, 2010, Pedoman Praktik Kerja Lapangan Integratif (PKLI). Malang: Fakultas Tarbiyah UIN Malang

Gumelar dan Dahyat, 2002, Supervisi Pendidikan Indonesia. Jakarta: Gramedia,

Hadi, Sutrisno. 1989. Statistik I dan II. Yogjakarta: Andi ofset.

Hariani, Muji dan Noeng Muhadjir. 1980. Evaluasi Kemampuan Mengajar. Jakarta: Proyek Pengembangan Pendidikan Guru (P3G). Depdikbud. 
Nur Ali - Evaluasi Program Praktik Keria Lapangan Integratif...

Indra Djati Sidi.2000, Pendidikan dan Peran Guru dalam Era Globalisasi, dalam majalah komunikasi no 55/tahun VIII/2000.)

Lincoln dan Guba, 1985.Naturalistic Inquiry, Baverly Hills California: Sage Publications, Inc.

Miles. B Matthew dan A. Michael Huberman 1992. Analisis Data Kualitatif. Penerbit Universitas Indonesia Jakarta.

Moleong, L. J. 2005.Metodologi Penelitian Kualitatif. Bandung: Remaja Karya.

Muhadjir, N. 1993, Ilmu Pendidikan dan Perubahan Sosial; Suatu Teori Pendidikan. Yogjakarta: Rake Sarasin.

Muhaimin, dkk. 2001.Paradigma Pendidikan Islam: Pemikiran dan Pengembangannya dalam Desain Pembelajaran, Bandung: Rineka Cipta.

Muhaimin. 2003. Wacana Pengembangan Pendidikan Islam. Yogjakarta: Pustaka Pelajar.

Muhadjir, N. 1993, Ilmu Pendidikan dan Perubahan Sosial; Suatu Teori Pendidikan. Yogjakarta: Rake Sarasin

Permendiknas nomor 19 tahun 2005 tentang Standar Nasional Pendidikan

Permenag nomor 16 tahun 2010 tentang Pengelolaan Pendidikan Agama pada Sekolah.

Sahertian, Piet. A. dan Ida A. S. 1990.Supervesi Pendidikan. Jakarta: Rineka Cipta.

Tilaar, HAR., 1999. Beberapa Agenda Reformasi Pendidikan Nasional dalam Perspektif Abad 21; Magelang: Indonesia Tera,

Tilaar, HAR., 2002. Pendidikan untuk Masyarakat Indonesia Baru. Jakarta: Grasindo.

Uzer Usman, M. 2001, Menjadi Guru Profesional, Bandung: Remaja Rosda Karya.

Undang-Undang No. 20 tahun 2003 tentang Sistem Pendidikan Nasional.

Undang-Undang No. 14 tahun 2005 tentang Guru dan Dosen. 